\title{
TEORES DE ÓlEO, PROTEÍNAS E PRODUTIVIDADE DE SOJA EM FUNÇÃO DA ANTECIPAÇÃO DA SEMEADURA NA REGIÃO OESTE DO PARANÁ $\left({ }^{1}\right)$
}

\author{
LEANDRO PAIOLA ALBRECHT $\left({ }^{2 *}\right)$; ALESSANDRO DE LUCCA E BRACCINI $\left({ }^{2,4}\right)$; \\ MARIZANGELA RIZZATTI ÁVILA $\left({ }^{2}\right)$; LETÍCIA SAYURI SUZUKI $\left({ }^{2}\right)$; CARLOS ALBERTO SCAPIM $\left({ }^{2,4}\right)$; \\ MAURO CEZAR BARBOSA $\left({ }^{3}\right)$
}

\begin{abstract}
RESUMO
A semeadura antecipada da soja, particularmente utilizando cultivares precoces, é prática que vem sendo adotada por muitos produtores paranaenses com o intuito de antecipar a colheita e viabilizar o cultivo de milho safrinha. Visando avaliar a influência da antecipação da semeadura na composição química e na produtividade da soja, foram instalados ensaios de competição de cultivares na unidade da COODETEC, em Palotina (PR). O delineamento foi em blocos casualizados, desenvolvido em dois anos agrícola (2003/2004 e 2004/2005), com três cultivares precoces (CD 202, CD 215 e CD 216), semeadas em cinco épocas $(15 / 9,30 / 9,15 / 10,30 / 10$ e 15/11). Foram determinados os teores de óleo e proteínas nos grãos. Partindo-se do rendimento de grãos nas parcelas, foram calculadas as produtividades em $\mathrm{kg} \mathrm{ha}^{-1}$. Os dados coletados foram submetidos à análise de variância conjunta e realizados os desdobramentos das interações quando necessários. Os resultados permitiram concluir que a antecipação da semeadura influenciou na produtividade e composição química dos grãos.
\end{abstract}

Palavras-chave: Glycine max, época de semeadura, produção, composição química.

\section{ABSTRACT \\ OIL AND PROTEIN CONTENTS AND YIELD OF SOYBEAN WITH EARLY SOWING IN WEST PARANÁ}

Early soybean sowing, especially using early cultivars is a practice that is adopted by many growers from the State of Paraná in order to anticipate harvest and to enhance growing corn crop during the fall. Experiments of soybean cultivars competition trials were carried out at COODETEC in the city of Palotina, Paraná State, aiming to evaluate the influence of early sowing on the chemical composition of seeds, as well as yield. A randomized block design, comprised by two crop years $(2003 / 2004$ and 2004/2005), three early cultivars (CD 202, CD 215 and CD 216); and five sowing times (09/15, 09/30, 10/15, 10/30 and $11 / 15)$ was utilized. Also, oil and protein content were also determined. The productivity $\left(\mathrm{kg} \mathrm{ha}^{-1}\right)$ was calculated using the yield of grain in each parcel. All data were submitted to variance analysis of group experiments along with all interactions and necessary adjustments. Results allowed to conclude that early sowing can influence grain yield and seed chemical composition.

Key words: Glycine max, sowing date, production, chemical composition.

$\left({ }^{1}\right)$ Recebido para publicação em 31 de janeiro de 2007 e aceito em 14 de maio de 2008.

$\left({ }^{2}\right)$ Departamento de Agronomia, Universidade Estadual de Maringá (UEM), Av. Colombo, 5790, 87020-900 Maringá (PR). E-mail: lpalbrecht@yahoo.com.br (*) Autor correspondente; albraccini@uol.com.br; cascapim@uem.br; marizangela_rizzatti@hotmail.com; leticiasuzuki@yahoo.com.br;

$\left({ }^{3}\right)$ Acadêmico de Mestrado em Agronomia, UEM, Maringá, PR; Fone: (44) 32287172; E-mail: mcezarbarbosa@hotmail.com

$\left({ }^{4}\right)$ Bolsista do CNPq. 


\section{INTRODUÇÃO}

A soja é considerada, mundialmente, a principal fonte de produção de óleos e proteínas vegetais para alimentação humana e animal (MANARA, 1988); e constitui, atualmente, um dos produtos de maior importância na economia brasileira, ocupando lugar de destaque na oferta de óleo para consumo interno, no arraçoamento animal como principal fonte protéica, bem como, na pauta de exportação do país (Sediyama et al., 1993). Também, no período entre 2000 e 2005, as exportações do complexo soja cresceram 80 \% (Moraes, 2006). Dada a sua importância, há intensa atividade de pesquisa dirigida à obtenção de informações para a cultura da soja que possibilitem aumentos na produtividade e redução nos custos de produção (EMBRAPA, 2003).

Considerando que a cultura da soja é influenciada por diversos fatores ao longo de seu ciclo, é relevante destacar a escolha da época de semeadura, como fator cultural que, isoladamente, mais promove o desenvolvimento das plantas e a produção da lavoura (MArcos Filho, 1986; Costa et al., 1995, EMBRAPA, 2005).

A instalação da cultura da soja em determinada época pode expor as plantas a estresse ambiental no campo, em uma fase específica do ciclo, ou até mesmo durante vários estádios vegetativos e/ ou reprodutivos, modificando sua composição química. Segundo RAO et al. (1993), as quantidades de óleo e proteínas também podem ser influenciadas pelo ambiente no qual o vegetal é cultivado.

Tanto Rangel et al. (2004) como Pípolo (2002) concordam que, em princípio, os teores de óleo e proteína dos grãos de soja são governados geneticamente, porém fortemente influenciados pelo ambiente, principalmente durante o período de enchimento dos grãos. O conteúdo de proteína nos grãos é quatro vezes mais dependente das condições ambientais do que da variedade (BenzaIn e LANE, 1986).

O período preferencial para a semeadura da soja no Estado do Paraná é o mês de novembro. No Estado do Paraná, a época de semeadura indicada, para a maioria das cultivares, estende-se de 15/10 a 15/12 (EMBRAPA, 2005). A semeadura antecipada, segundo a Embrapa (2005), é aquela realizada antes de 15 de outubro. Pode ser praticada em regiões mais quentes do Estado, onde ocorre inverno úmido, solos de alta fertilidade e temperaturas favoráveis à emergência das plantas desde o início de outubro. Estas condições são mais comuns na Região Oeste do Paraná, nas áreas de menor altitude, mais próximas do Rio Paraná, localizadas entre o Rio Piquiri e Iguaçu.
O objetivo do presente trabalho foi avaliar a influência da antecipação da semeadura nos teores de óleo e proteínas e na produtividade de grãos de três cultivares precoces de soja, em dois anos agrícolas.

\section{MATERIAL E MÉTODOS}

Este trabalho foi instalado nos anos agrícolas de 2003/2004 e 2004/2005, em área localizada na Unidade da Cooperativa Central de Pesquisa Agrícola (COODETEC), em Palotina (PR), em Latitude: $24^{\circ} 18^{\prime}$ '; Longitude: $53^{\circ} 55^{\prime} \mathrm{W}$; Altitude: $310 \mathrm{~m}$; Classe do Solo: Latossolo Vermelho eutroférrico, A moderado, textura muito argilosa. A composição química dos grãos foi avaliada no Laboratório de Tecnologia de Sementes do Núcleo de Pesquisas Aplicadas à Agricultura (NUPAGRI), pertencente à Universidade Estadual de Maringá, em Maringá (PR).

O clima predominante na região é do tipo $\mathrm{Cfa}$, mesotérmico úmido, com chuvas abundantes no verão e inverno seco, e verões quentes, segundo classificação de Köppen. Foram coletados dados diários de precipitação pluvial e temperatura máxima e mínima, referentes aos períodos de duração dos ensaios, nos anos agrícolas de 2003/2004 e 2004/2005.

Foram instalados cinco ensaios de competição de cultivares, com três tratamentos e quatro repetições, semeando-se um ensaio em cada época de plantio $(15 / 9,30 / 9,15 / 10,30 / 10$ e 15/11). As três cultivares de soja avaliadas foram CD 202, CD 215 e CD 216, todas pertencentes ao grupo de maturação precoce (COODETEC, 2005).

O sistema de preparo do solo adotado foi em semeadura direta e a adubação e demais práticas culturais foram as mesmas preconizadas pelo sistema de produção da região (EMBRAPA, 2003). O solo da área experimental foi analisado quanto às características químicas e a adubação realizada de acordo com as recomendações sugeridas pela EMBRAPA (2003). A área útil das unidades experimentais foi de $7,2 \mathrm{~m}^{2}$.

Quanto à semeadura, deixou-se cerca de 16 plantas por metro linear (densidade de 355.555 plantas ha $^{-1}$ ). A irrigação, por aspersão, foi fornecida somente logo após a semeadura para garantir o estabelecimento inicial das plantas.

As plantas foram colhidas manualmente, cinco a oito dias após o estádio $\mathrm{R}_{8}$ de desenvolvimento (FeHr et al., 1971), quando os grãos estavam com grau de umidade abaixo de $15 \%$ (base úmida). Após a colheita das plantas, os grãos de soja foram debulhados das vagens em máquina trilhadeira estacionária, limpos com o auxílio de peneiras, secados em condições naturais, acondicionados em 
sacos de papel kraft multifoliado e mantidos em câmara fria, a $10^{\circ} \mathrm{C}$ de temperatura e $50 \%$ de umidade relativa, do fim da colheita ao início das avaliações de laboratório.

Partindo-se do rendimento de grãos nas parcelas, foram calculadas as produtividades em $\mathrm{kg}$ $\mathrm{ha}^{-1}$. Os dados de produtividade foram corrigidos para $13 \%$ de umidade (base úmida). O grau de umidade dos grãos foi avaliado por meio do método de estufa a 105 ${ }^{\circ} \mathrm{C}$ por 24 horas (Brasil, 1992).

Determinação de proteína: foi realizada utilizando-se o método de Kjeldahl, na quantificação de nitrogênio total, conforme recomendação da Association of Official Analytical Chemist (1975) e VITTI et al. (2001), com modificações. Foram analisadas quatro subamostras de $0,2 \mathrm{~g}$ da farinha de soja moída, provenientes de amostras dos grãos de cada repetição de campo. A farinha de soja moída foi condicionada em tubos de ensaio, junto com $2 \mathrm{~g}$ de uma mistura catalítica (sulfato de cobre e selênio em pó) e $5 \mathrm{~mL}$ de ácido sulfúrico concentrado. Estes tubos foram levados para aquecimento em um bloco digestor para a fase de digestão da matéria orgânica. O aquecimento foi gradual e assim que a temperatura de $350{ }^{\circ} \mathrm{C}$ foi atingida, o material permaneceu a esta temperatura constante por mais 2,5 horas. Após a obtenção do material digerido, iniciou-se a fase de destilação da amônia liberada e, após a reação com hidróxido de sódio (50\%), foi recolhida em solução de ácido bórico a $4 \%$. A titulação foi realizada em solução-padrão de ácido clorídrico a $1 \mathrm{~N}$. Obteve-se para esse procedimento uma recuperação de $99,7 \%$ de nitrogênio. Para o cálculo da conversão de nitrogênio em proteínas, foi utilizado o fator 6,25 e a porcentagem de proteínas foi obtida com base na matéria seca.

Determinação de óleo: na avaliação dos lipídios totais (óleo), utilizou-se o aparelho extrator de Soxhlet e éter de petróleo como solvente, segundo o procedimento descrito nas Normas Analíticas do InSTituto Adolfo Lutz (1985), com refluxo de 6 horas. Foram avaliadas quatro subamostras de $2 \mathrm{~g}$ de cada repetição de campo, provenientes dos grãos previamente moídos. Os resultados foram expressos em porcentagem de óleo extraído, determinado por diferença de pesagem.

O delineamento experimental foi em blocos completos casualizados com quatro repetições de campo, em que cada época de semeadura constituiuse de ensaio individual de competição de cultivares de soja, em dois anos agrícolas. Os dados obtidos para todas as variáveis em cada um dos ensaios individuais, para os dois anos, foram submetidos à análise de variância; em seguida, verificou-se a semelhança dos quadrados médios do resíduo pelo teste de Hartley (RAmALHO et al., 2000) e a razão entre o maior e o menor quadrado médio residual (PIMENTELGOMES e GARCIA, 2002) foi inferior a sete, permitindo à análise conjunta.

Para análise dos resultados foram considerados os efeitos fixos (cultivar e época) e efeitos aleatórios (ano). Foram calculadas as esperanças do quadrado médio - $\mathrm{E}(\mathrm{QM})$ - conforme modelo biométrico adotado e, segundo pressupostos de Cruz et al. (2004). Independentemente da significância pelo teste $F$ $(p<0,05)$, na interação de segunda ordem (ano $x$ cultivar $\mathrm{x}$ época), efetuaram-se os desdobramentos necessários.

As médias de cultivares foram comparadas pelo teste de Newman Keuls ( $p<0,05)$, enquanto para testar anos, o próprio teste $\mathrm{F}$ foi conclusivo. A análise de regressão foi realizada para verificar o comportamento das características em função das épocas de semeadura.

\section{RESULTADOS E DISCUSSÃO}

Os dados climáticos coletados nos anos agrícolas de 2003/2004 e 2004/2005 estão listados na figura 1. Os dados de temperatura obtidos durante o período de execução do experimento tenderam a ser superiores ao histórico da região (IAPAR, 2006), em especial em 2004/ 2005, com média térmica e picos de máxima superiores, marcadamente nos últimos meses do experimento.

A ocorrência de precipitação pluvial foi relativamente baixa durante o período de execução do experimento, para ambos os anos agrícolas. No ano agrícola de 2003/2004, a média mensal foi de $111 \mathrm{~mm}$ e o total no período de $777 \mathrm{~mm}$. Em 2004/2005, a média mensal e o acumulado em $\mathrm{mm}$ foi superior a 2003/2004, sendo, respectivamente, de 120 e 846 mm.

A observação mais destacada concerne ao comportamento e à distribuição das chuvas. A restrição hídrica no ano agrícola de 2003/2004 foi mais acentuada, no que concerne a alguns meses, enquanto para 2004/2005, o déficit hídrico ocorreu, mas não tão acentuado, pois esteve disperso por mais meses, o que atenuou o seu efeito negativo, de acordo com Sionit e Kramer (1977), Rassini e Lin (1981), Marcos Filho (1986) e Marcos Filho (2005).

Pelos resultados dos teores médios de óleo nos grãos (Tabela 1), com uma única exceção, observaramse o mesmo comportamento em todas as épocas de semeadura, na comparação dos diferentes anos agrícolas. Nota-se que o segundo ano $(2004 / 2005)$ foi sempre superior no teor de óleo, salvo na primeira época de semeadura para a cultivar CD 216, em que não houve diferença significativa entre as safras avaliadas. 

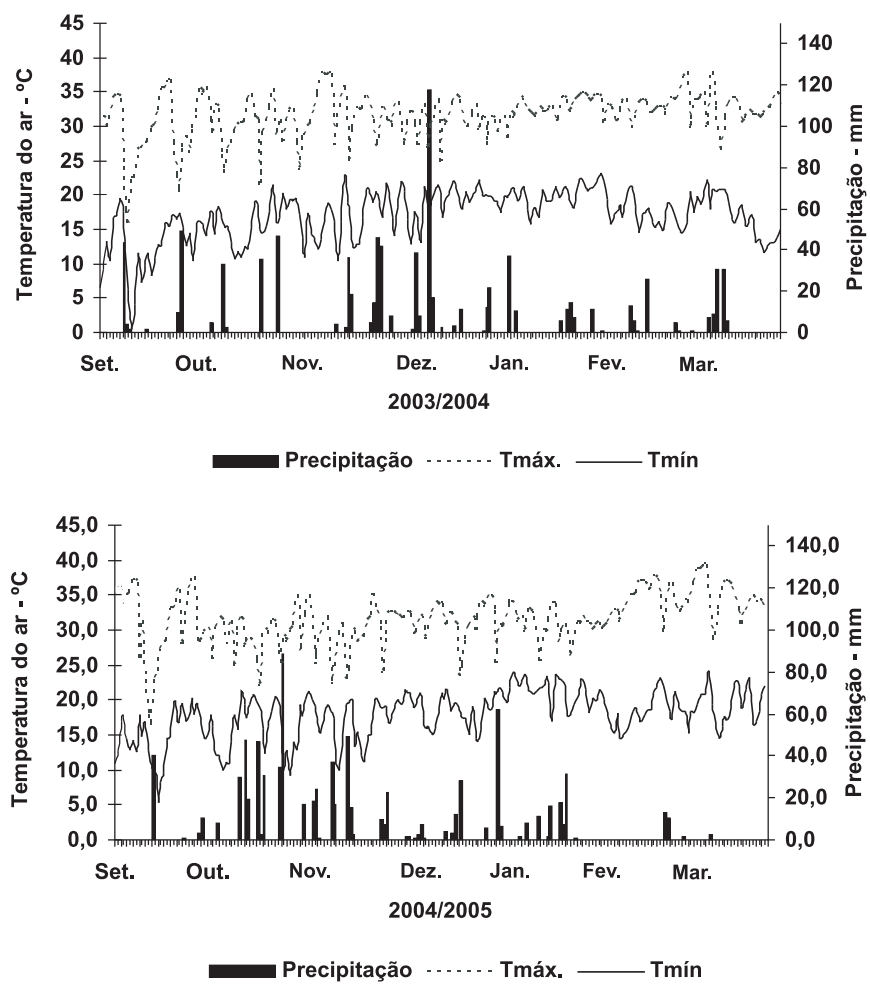

Figura 1. Temperaturas médias de máxima e mínima e precipitação pluvial, em Palotina (PR), entre setembro a março do ano agrícola de 2003/2004 e 2004/2005. Fonte: IAPAR, 2006.

Atribui-se os maiores teores de óleo no segundo ano agrícola e os maiores teores de proteínas no primeiro ano agrícola, às de diferenças climáticas existentes entre os anos, resultados em consonância com FonTEs et al. (1974).

Merecem menção especial as maiores restrições hídricas observadas, em quase todas as épocas, no período reprodutivo das cultivares no primeiro ano agrícola $(2003 / 2004)$, que elevaram os teores de proteínas, o que está de acordo com BEWLEY e BLACK (1985) e Marcos Filho (2005). Destacam-se, também, as maiores temperaturas médias no período reprodutivo da cultura, no segundo ano (Tabela 1), que favoreceram o acúmulo de óleo nos grãos, concordando com HowelL e CARTER (1953) e URBEn e Souza (1993).

Quanto à variação percentual de óleo e proteína, no primeiro ano, a variação foi de $11,29 \%$ a $20,17 \%$ para óleo e de $35,47 \%$ a $43,23 \%$ para proteína. No segundo ano, a variação foi de $21,22 \%$ a $32,45 \%$ para o teor de óleo e de $24,60 \%$ a $34,15 \%$ para o teor de proteína, levando-se em conta as médias de todas as cultivares e em todas as épocas de semeadura.

No primeiro ano agrícola, a amplitude dos teores de óleo e de proteínas nos grãos de soja esteve próxima das médias constatadas na literatura. A variação nos teores de óleo, para o segundo ano, estão concordantes com a bibliografia consultada; porém, no caso dos teores de proteínas, estes foram inferiores ou próximos do registrado por autores como HyMowitz et al. (1972), Popinigs (1985), BEWLEY e BLACK (1985), Sediyama et al. (1993) e Marcos Filho (2005).

Entre as cultivares avaliadas, só foram observadas diferenças significativas, dentro de cada época de semeadura e de cada ano agrícola, apenas na quinta época $(15 / 11)$ do segundo ano $(2004 / 2005)$, tanto para teores de óleo, como de proteína. A diferença observada somente na quinta época de semeadura, para o segundo ano, ocorreu em virtude de severo estresse ambiental, que aliou a nítida deficiência hídrica, na fase final de enchimento dos grãos, a elevadas temperaturas máximas, possivelmente, um duplo estresse que levou a efeitos fisiológicos, acarretando distúrbios bioquímicos nas biossínteses de óleo e de proteínas. É interessante notar que as diferenças revelam a existência, diante do estresse constatado, de comportamento diferencial entre os genótipos, quanto à regulação metabólica que determina a síntese de proteínas e óleo, e que, possivelmente, deve afetar outras macromoléculas, estendendo-se, provavelmente, a influência na síntese de vários outros compostos, ou primários ou secundários.

Os resultados referentes aos teores de óleo e de proteínas das três cultivares, nos dois anos agrícolas, em função das épocas de semeadura da soja, são apresentados nas figuras 2 e 3. Observa-se que, no segundo ano agrícola $(2004 / 2005)$, não houve diferença significativa $(p<0,05)$ entre épocas de semeadura, para todas as cultivares e para ambos os teores (óleo e proteína) (Figuras 2B e 3B). Supõe-se que as oscilações de temperatura e pluviosidade não foram suficientes para alterar, significativamente, os teores dos componentes químicos avaliados, na referida safra.

No primeiro ano (Figuras 2A e 3A), tanto para o teor de proteínas, quanto para o de óleo, ocorreu diferença significativa, permitindo o ajuste de equações que melhor explicassem a interação. Quanto aos teores de óleo (Figura 2A), nas três cultivares havia tendência linear crescente em virtude da antecipação da época de semeadura da soja; na variável teor de proteínas, foi o inverso, ou seja, a tendência foi linear, mas foi decrescente, em vista da antecipação da época de semeadura. Esses resultados caracterizam bem a correlação negativa existente entre os conteúdos de óleo e de proteínas, na composição química dos grãos, concordando com RANGeL et al. (2004). Esse fato condiz, também, com o relatado por Hanson (1991) e Pípolo (2002), segundo os quais haveria uma correlação negativa entre os níveis de óleo e proteínas nos grãos, explicado pela concorrência dessas duas vertentes pelos esqueletos carbônicos. 
Tabela 1. Teores de óleo e proteína, em porcentagem, nas sementes de três cultivares de soja, produzidas em cinco épocas de semeadura, nas safras de 2003/2004 e 2004/2005, em Palotina (PR)

\begin{tabular}{|c|c|c|c|c|c|c|}
\hline \multirow{3}{*}{ Cultivar $^{1}$} & \multicolumn{2}{|c|}{ Óleo } & \multirow{3}{*}{ Média } & \multicolumn{2}{|c|}{ Proteína } & \multirow{3}{*}{ Média } \\
\hline & \multicolumn{2}{|c|}{ Ano agrícola ${ }^{2}$} & & \multicolumn{2}{|c|}{ Ano agrícola $\left({ }^{2}\right)$} & \\
\hline & $2003 / 04$ & $2004 / 05$ & & $2003 / 04$ & $2004 / 05$ & \\
\hline & & & $15 / 9$ & & & \\
\hline CD 202 & $20,17 \mathrm{Ab}$ & $27,73 \mathrm{Aa}$ & 23,95 & $35,47 \mathrm{Aa}$ & $27,92 \mathrm{Ab}$ & 31,70 \\
\hline CD 215 & $18,40 \mathrm{Ab}$ & $27,80 \mathrm{Aa}$ & 23,10 & $36,96 \mathrm{Aa}$ & $30,47 \mathrm{Ab}$ & 33,72 \\
\hline CD 216 & $18,66 \mathrm{Aa}$ & $22,54 \mathrm{Aa}$ & 20,60 & $38,14 \mathrm{Aa}$ & $30,98 \mathrm{Ab}$ & 34,56 \\
\hline Média & 19,08 & 26,02 & - & 36,86 & 29,79 & - \\
\hline & & & $30 / 9$ & & & \\
\hline CD 202 & $19,04 \mathrm{Ab}$ & $25,68 \mathrm{Aa}$ & 22,36 & $37,25 \mathrm{Aa}$ & $26,20 \mathrm{Ab}$ & 31,73 \\
\hline CD 215 & $19,16 \mathrm{Ab}$ & $26,67 \mathrm{Aa}$ & 22,92 & $39,39 \mathrm{Aa}$ & $24,60 \mathrm{Ab}$ & 32,00 \\
\hline CD 216 & $18,85 \mathrm{Ab}$ & $24,31 \mathrm{Aa}$ & 21,58 & $40,22 \mathrm{Aa}$ & $26,11 \mathrm{Ab}$ & 33,17 \\
\hline Média & 19,02 & 25,55 & - & 38,95 & 25,64 & - \\
\hline & & & $15 / 10$ & & & \\
\hline CD 202 & $15,99 \mathrm{Ab}$ & $29,88 \mathrm{Aa}$ & 22,94 & $41,72 \mathrm{Aa}$ & $28,88 \mathrm{Ab}$ & 35,30 \\
\hline CD 215 & $16,30 \mathrm{Ab}$ & 29,49 Аа & 22,90 & 41,98 Аа & $29,92 \mathrm{Ab}$ & 35,95 \\
\hline CD 216 & $18,32 \mathrm{Ab}$ & $28,79 \mathrm{Aa}$ & 23,56 & $42,52 \mathrm{Aa}$ & $30,49 \mathrm{Ab}$ & 36,51 \\
\hline Média & 16,87 & 29,39 & - & 42,08 & 29,76 & - \\
\hline & & & $30 / 10$ & & & \\
\hline CD 202 & $15,49 \mathrm{Ab}$ & $28,20 \mathrm{Aa}$ & 21,85 & $41,05 \mathrm{Aa}$ & $28,56 \mathrm{Ab}$ & 34,81 \\
\hline CD 215 & $17,61 \mathrm{Ab}$ & $26,18 \mathrm{Aa}$ & 21,90 & $41,50 \mathrm{Aa}$ & $29,82 \mathrm{Ab}$ & 35,66 \\
\hline CD 216 & $16,17 \mathrm{Ab}$ & $27,74 \mathrm{Aa}$ & 21,96 & $41,77 \mathrm{Aa}$ & $28,58 \mathrm{Ab}$ & 35,18 \\
\hline Média & 16,42 & 27,37 & & 41,44 & 28,99 & \\
\hline & & & $15 / 11$ & & & \\
\hline CD 202 & $11,29 \mathrm{Ab}$ & $25,30 \mathrm{Ba}$ & 18,30 & $43,23 \mathrm{Aa}$ & $34,15 \mathrm{Ab}$ & 38,69 \\
\hline CD 215 & $13,10 \mathrm{Ab}$ & $32,45 \mathrm{Aa}$ & 22,78 & $42,39 \mathrm{Aa}$ & $29,13 \mathrm{Bb}$ & 35,76 \\
\hline CD 216 & $12,85 \mathrm{Ab}$ & $21,22 \mathrm{Ba}$ & 17,04 & $42,30 \mathrm{Aa}$ & $26,84 \mathrm{Bb}$ & 34,57 \\
\hline Média & 12,41 & 26,32 & - & 42,64 & 30,04 & - \\
\hline CV (\%) & \multicolumn{2}{|c|}{13,33} & & \multicolumn{2}{|c|}{8,57} & \\
\hline
\end{tabular}

( $\left.{ }^{1}\right)$ Médias seguidas de mesma letra maiúscula, em cada coluna, não diferem entre si pelo teste de Newman Keuls, a 5 \% de probabilidade.

$\left({ }^{2}\right)$ Médias seguidas de mesma letra minúscula, em cada linha, não diferem entre si pelo teste $\mathrm{F}$, a $5 \%$ de probabilidade.

Tendo as equações ajustadas como base, podese afirmar que para cada dia após $15 / 9$, no primeiro ano agrícola, os teores de óleo decrescem em 0,1421\% (coeficiente angular), do máximo de $20,66 \%$, para a cultivar CD 202. Na cultivar CD 215, a diminuição diária é de 0,0815\%, em relação ao máximo de 19,34\%. Por sua vez, na cultivar CD 216, o decréscimo é de 0,0953\% por dia, do máximo de 19,83\% (Figura 2A).

Observando os resultados dos teores percentuais de proteína nos grãos, no primeiro ano, na cultivar CD 202 houve aumento de $0,1288 \%$ ao dia, até alcançar o máximo de $43,61 \%$. Na cultivar CD 215, visualiza-se crescimento diário de $0,0865 \%$ até chegar ao patamar de $43,04 \%$. Para a cultivar CD 216, o aumento foi de $0,0658 \%$ ao dia, até $42,96 \%$ (Figura 3 A).
Variações climáticas no período de transferência de matéria seca, como é o caso de deficiência hídrica, podem alterar a fisiologia do vegetal. A restrição hídrica pode acelerar a maturação e reduzir o período de acúmulo de reservas, fazendo com que os grãos das plantas estressadas não apresentem o padrão normal de desenvolvimento e composição química (Delouche, 1980; Carvalho e Nakagawa, 1988; Marcos Filho, 2005). O estresse hídrico, somado ao efeito da temperatura podem explicar as variações na concentração da proteínas (PíPOLO, 2002; RANGel et al., 2004). Quando não é possível explicar a diferença nos teores de proteína na soja, entre épocas de semeadura, pela oscilação térmica, pode-se explicar pela distribuição de chuvas durante o período de enchimento de grãos e a disponibilidade de nitrogênio (PíPOLO, 2002). 

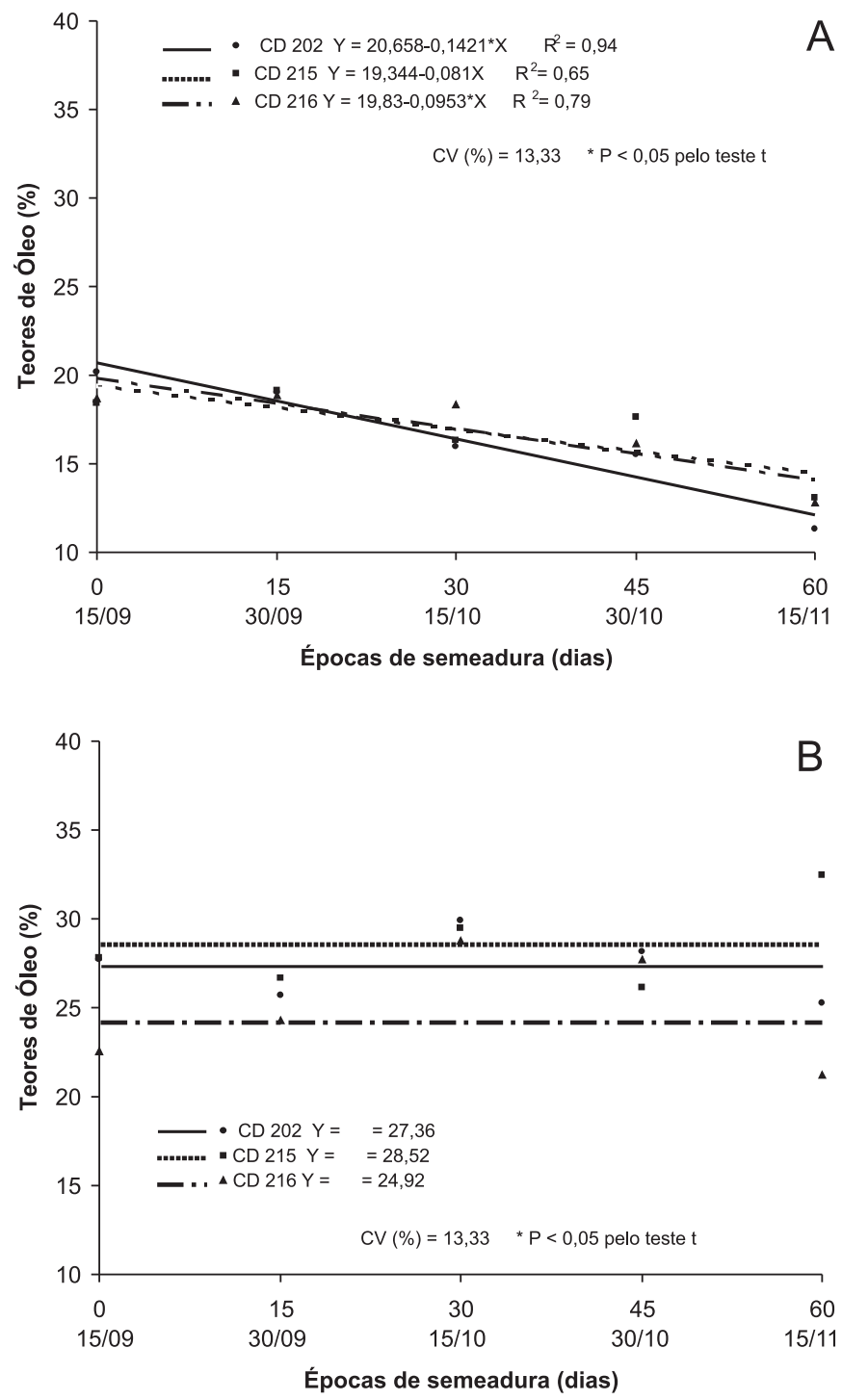

Figura 2. Regressão polinomial para os teores de óleo nas sementes de três cultivares de soja, produzidas em cinco épocas de semeadura, nos anos agrícolas de 2003/ 2004 (A) e 2004/ 2005 (B), em Palotina (PR).

A relação, segundo SediYAmA et al. (1993), entre cultivar e época de semeadura, quanto ao teor de óleo nos grãos de soja, ocorre em função da temperatura durante a fase de enchimento da vagem.

$\mathrm{O}$ abastecimento de $\mathrm{N}$, em conseqüência de eficiente nodulação e concomitante processo simbiótico de fixação, é influenciado negativamente por déficit hídrico. No entanto, a falta de água afeta toda a fisiologia da planta, e não somente o aparato fisiológico formado pelas rotas bioquímicas de fixação simbiótica (dentro do bacterióide) e do metabolismo do $\mathrm{N}$ (envolvendo rotas de redução e assimilação do N). Confirma-se, portanto, que a maior sensibilidade do sistema de fixação biológica do nitrogênio, é reflexo da elevação da temperatura do ar que, somada à
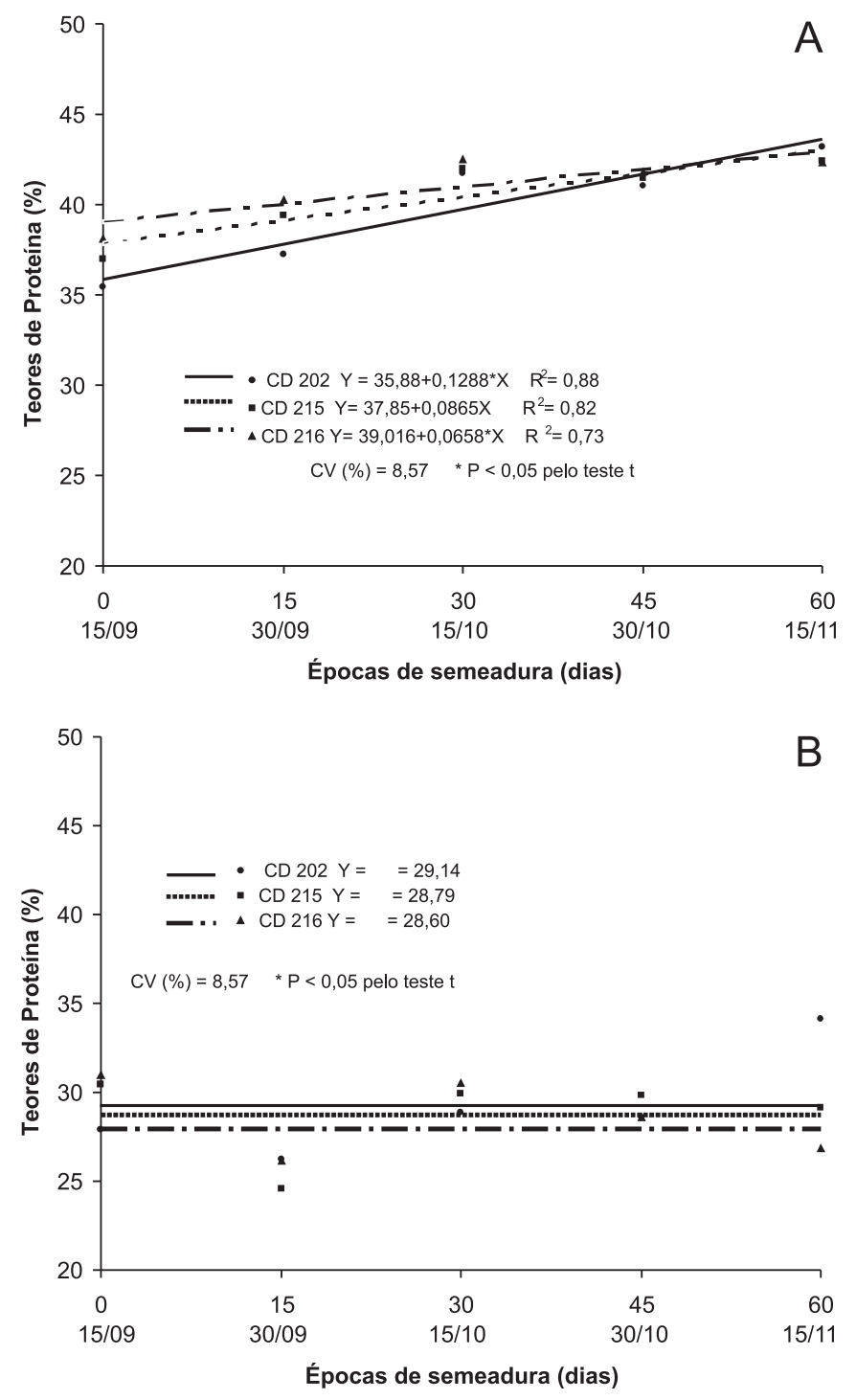

Figura 3. Regressão polinomial para os teores de proteína nas sementes de três cultivares de soja, produzidas em cinco épocas de semeadura, nos anos agrícolas de 2003/ 2004 (A) e 2004/2005 (B), em Palotina (PR).

radiação solar exacerbada no verão, aumentam a temperatura do solo, afetando os nódulos radiculares, coincidindo com a época de alta demanda de compostos nitrogenados, que é a da fase reprodutiva da cultura. As observações concordam com as de diversos autores, como Howell e CARTter (1953), Bewley e Black (1985), Urben Filho e Souza (1993), Hungria et al. (2000), Taiz e Zeiger (2004) e Marcos FiLHo (2005), que discorreram, também, sobre o efeito isolado e/ou associado de baixa disponibilidade hídrica e altas temperaturas.

Ecofisiologicamente, os fatores ambientais podem tornar-se estressores quando não atendem satisfatoriamente a necessidade dos vegetais ou quando atingem níveis deletérios à atividade 
bioquímica e fisiológica da planta. Analisando especificamente o primeiro ano agrícola (2003/2004), a restrição hídrica foi preponderante (Tabela 1) e o efeito da alta temperatura não foi tão expressivo, a ponto de reduzirem os teores de óleo com o atraso da semeadura, na competição por carbono biossintético (Figuras 2 e 3).

Na produtividade das cultivares, dentro de cada época e de cada ano, não ocorreu diferença significativa $(\mathrm{p}<0,05)$. Observou-se, pela produtividade de todas as cultivares na quarta e quinta época, para o segundo ano, que as médias foram significativamente maiores no primeiro ano, possivelmente em virtude da maior restrição hídrica verificada na fase reprodutiva da cultura da soja semeada nas últimas épocas no primeiro ano agrícola, aliada a altas temperaturas.

A floração é severamente afetada pela deficiência de água no período de duas a quatro semanas que precede a diferenciação floral (SACCOL, 1975), mas o período de transferência de matéria seca é o mais crítico para a soja, em relação a esse fator, pois restringe a área foliar, induz o aborto de legumes, acelera a senescência das folhas e, conseqüentemente, a massa e o número dos grãos. A menor disponibilidade de água promove decréscimo da fotossíntese e abrevia o período de enchimento dos grãos, com prejuízo à produção (França Neto e KrZYZANOWSKI, 1990). Temperaturas elevadas, principalmente quando associadas a períodos com baixos índices pluviométricos durante a maturação, podem ocasionar maturação "forçada", sendo produzidas, nessas condições, sementes de baixo vigor, em virtude de não se verificar a deposição natural de carboidratos, lipídios e proteínas (FrANÇA Neto et al., 1993), já que houve redução da translocação de fotossintatos para os grãos. MARCos FiLho (2005) afirma que temperaturas elevadas são consideradas as principais responsáveis pela maturação "forçada" em soja, provocando a translocação muito rápida das reservas, levando à inadequada maturação.

Na produtividade referente ao ano agrícola de 2003/2004 (Figura 4A) houve tendência linear decrescente para as cultivares CD 202 e CD 215. Pela equação linear ajustada, é possível inferir, para cada dia que se prolonga a semeadura, após 15/9, que há um decréscimo de $62,43 \mathrm{~kg} \mathrm{ha}^{-1}$ para a cultivar CD 202, e de 56,09 $\mathrm{kg} \mathrm{ha}^{-1}$ para CD 215.

Houve tendência quadrática para a cultivar CD 216, provavelmente devido à sua maior precocidade, sofrendo mais com a antecipação da semeadura, ou seja, ciclo menor, menos tempo para se recuperar de condições adversas iniciais, como temperaturas do ar e do solo baixas, menor precipitação pluvial e insuficiência fotoperiódica (BARNI e BERGAMASCHI, 1981). O ponto de máxima para a cultivar CD 216, no primeiro ano, foi de 14,76 dias, com produtividade de $3.197,80 \mathrm{~kg} \mathrm{ha}^{-1}$.
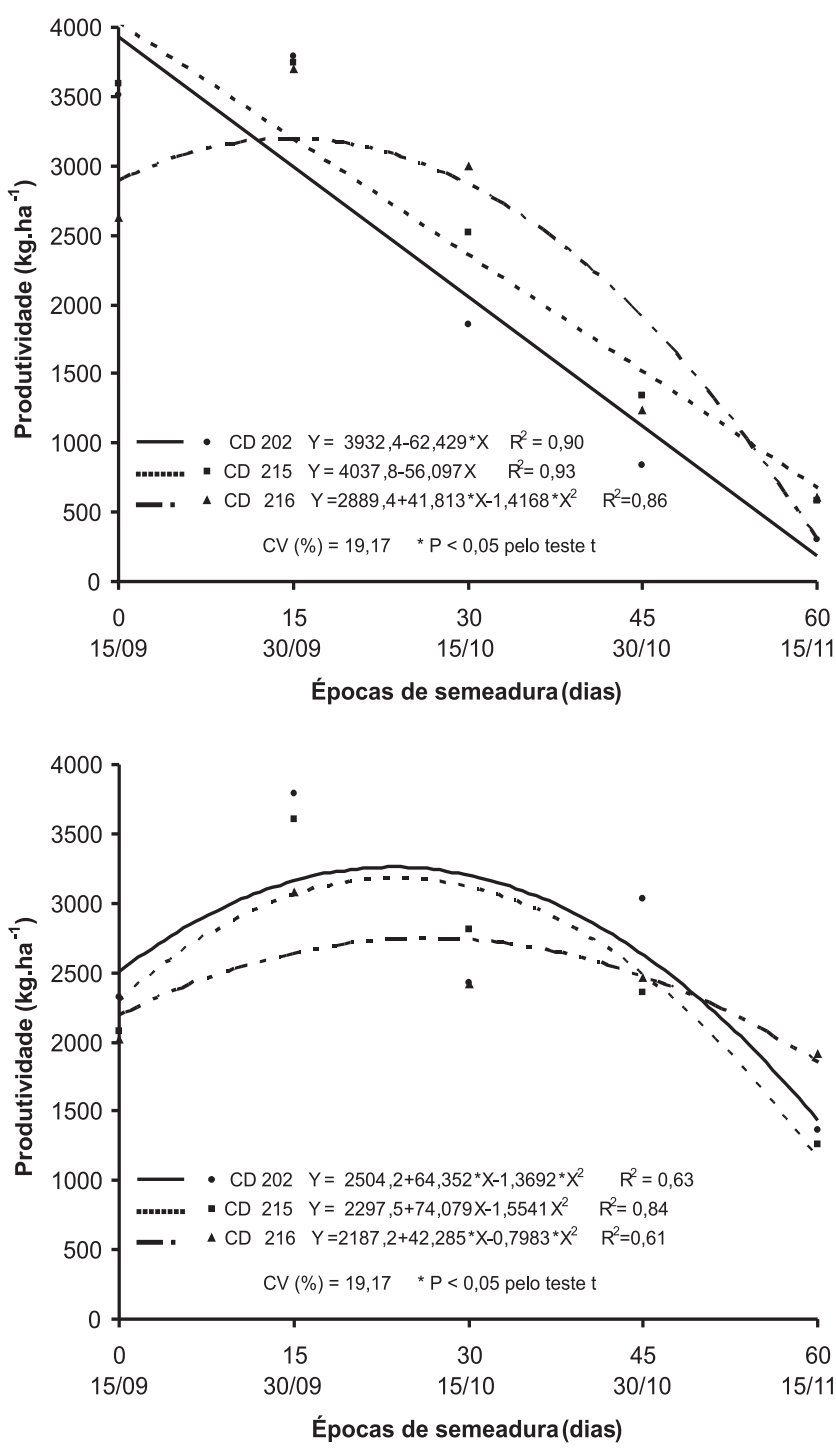

Figura 4. Regressão polinomial para produtividade das sementes de três cultivares de soja, produzidas em cinco épocas de semeadura, nos anos agrícolas de 2003/2004 (A) e 2004/2005 (B), em Palotina (PR).

A mesma situação, de comportamento quadrático, observou-se no segundo ano para todas as cultivares, em termos de produtividade (Figura 4B). Apesar de serem anos com algumas particularidades climáticas distintivas, as conjecturas supracitadas podem ser admitidas para o segundo ano. Os pontos de máxima fornecidos pelas equações foram de 23,50 (CD 202), 23,83 (CD 215) e 26,48 (CD 216) dias após 15/9. Novamente, a cultivar CD 216, foi a menos tolerante à antecipação na semeadura. 
Portanto, a época preferencial não foi a mais favorável para a produção de grãos em nenhum do dois anos em estudo, para nenhuma cultivar, em função do severo estresse por deficiência hídrica, somado a altas temperaturas (SACCOL, 1975; BERGAMIN et al., 1999; LARCher, 2000; TAIZ e Zeiger, 2004; Embrapa, 2005;), mais evidente no primeiro ano agrícola.

Vários estudos têm correlacionado negativamente o teor de proteínas nos grãos com a produtividade da soja. Esse fato pode ser parcialmente explicado pelo trabalho de Pípolo (2002), em que, no ano agrícola de 1998/1999, o rendimento médio de grãos foi de $1,52 \mathrm{t} \mathrm{ha}^{-1}$, com teor médio de $40,24 \%$ de proteínas, equivalendo a $98 \mathrm{~kg} \mathrm{ha}^{-1}$ de nitrogênio acumulado nos grãos. No ano agrícola de 1999/2000, o rendimento médio foi de 2,35 $\mathrm{t} \mathrm{ha}^{-1}$, com teor de proteínas de $37,22 \%$, equivalendo, por sua vez, a $140,10 \mathrm{~kg} \mathrm{ha}^{-1}$ de nitrogênio nos grãos. Portanto, mesmo tendo acumulado, em termos absolutos, maior quantidade de nitrogênio por hectare na safra de 1999/2000, sua concentração foi diluída em maior massa de grãos, resultando em menor percentual.

Neste trabalho, essa correlação negativa entre proteína e produtividade pode ser notada observandose as tendências nas figuras $3 \mathrm{~A}$ e $4 \mathrm{~A}$, em que para as cultivares CD 202 e CD 215, as produtividades decresceram linearmente, enquanto os teores de proteína cresceram linearmente, para todas as cultivares. Segundo Hanson (1992) e Rangel et al. (2004) genótipos com maior duração do período de enchimento de grão tem menor taxa de acumulação de matéria seca e maior produtividade, em condições favoráveis. Porém, na ocorrência de estresse hídrico durante o período reprodutivo, essa vantagem não se faz valer. Genótipos com alto nível de proteína tiveram baixas produtividades, curta duração do período de enchimento de grão e rápidas distribuições do $\mathrm{N}$ e acumulação da matéria seca.

\section{CONCLUSÕES}

1. Ecofisiologicamente, a semeadura em 15/ 11 e a antecipação para 15/9 não são favoráveis à obtenção de produtividades superiores para a soja no Oeste do Paraná;

2. A cultivar CD 216 é mais sensível, em relação aos genótipos CD 202 e CD 215, à antecipação da semeadura para 15/09;

3. A antecipação na semeadura propicia condições climáticas que tendem a aumentar os teores de óleo e reduzir os de proteínas.

\section{REFERÊNCIAS}

ASSOCIATION OF OFFICIAL ANALYTICAL CHEMISTS. Official methods of analysis. Washington: 1975. 1054 p.

BARNI, N.A.; BERGAMASCHI, H. Alguns princípios técnicos para a semeadura. In: MIYASAKA, S.; MEDINA, J.C. (Ed.). A soja no Brasil. São Paulo: ITAL, 1981. p.476-480.

BENZAIN, B.; LANE, P.W. Protein concentration of grains in relation to some weather and soil factors during 17 years of English winter-wheat experiments. Journal of Science of Food and Agriculture, Barking, v. 37, p. 435-444, 1986.

BERGAMIN, M.; CANCIAN, M.A.E.;CASTRO, P.R.C. Ecofisiologia da soja. In: CASTRO, P.R.C. e KLUGE, R.A. (Org.). Ecofisiologia de cultivos anuais: trigo, milho, soja, arroz e mandioca. São Paulo: Nobel, 1999. p.73-90.

BEWLEY, J.D.; BLACK, M. Seeds: Physiology of development and germination. New York: Plenum Press, 1985. 367p.

BRASIL. Ministério da Agricultura e Reforma Agrária. Regras para análise de sementes. Brasília: DNDV/SNAD/CLAV, 1992. 365p.

CARVALHO, N.M.; NAKAGAWA, J. (Coord.). Sementes: ciência, tecnologia e produção. 3.ed. Campinas: Fundação Cargill, 1988. 424p.

COODETEC - Cooperativa Central de Pesquisa Agrícola. Prospecto técnico de cultivares. Cascavel: COODETEC, 2005.

COSTA, N.P.; FRANÇA NETO, J.B.; HENNING, A.A.; KRZYZANOWSKI, F.C.; CABRAL, N.T.; MENDES, M.C. Efeito da época de semeadura sobre a qualidade fisiológica de sementes de soja no Estado do Mato Grosso. Revista Brasileira de Sementes, Brasília, v.17, n.1, p.107-112, 1995.

CRUZ, C.D.; REGAZZI, A.J.; CARNEIRO, P.C.S. Modelos biométricos aplicados ao melhoramento genético. 3.ed. Viçosa: UFV, 2004. p.50-101.

DELOUCHE, J.C. Environmental effects on seed development and seed quality. HortScience, Alexandria, v.15, n.6, p. 775$780,1980$.

EMBRAPA. Tecnologias de produção de soja - Paraná - 2006. Londrina: Embrapa Soja, 2005. 208p. (Sistemas de Produção, 8)

EMBRAPA. Tecnologias de produção de soja - Paraná 2003/04. Londrina: Embrapa Soja, 2003. 218p. (Sistemas de Produção, 3)

FEHR, W.R.; CAVINESS, C.E.; GURMOOD, D.T.; PENNINGTON, J.S. Stage of development description for soybean, Glycine max (L.) Merrill. Crop Science, Madison, v.11, n.6, p.929-931, 1971.

FONTES, L.G.; FILHO, J.A.; SEDIYAMA, C.S. Conteúdo de óleo e proteína bruta nos grãos de algumas linhagens e variedades de soja [Glycine max (L.) Merrill]. Revista Ceres, Viçosa, v.21, n.118, p.500-505, 1974. 
FRANÇA NETO, J.B.; KRZYZANOWSKI, F.C. Sementes enrugadas: novo problema na soja. Londrina: Embrapa soja, 1990. 4p. (Comunicado Técnico, 46)

FRANÇA NETO, J.B.; KRZYZANOWSKI, F.C.; HENNING, A.A.; WEST, S.H.; MIRANDA, L.C. Soybean seed quality as affected by shiveling due to heat and drought stress during seed filling. Seed Science and Technology, Zürich, v.21, n.1., p.107-116, 1993.

HANSON, W.D. Modified seed maturation and seed yield potentials in soybean. Crop Science, Madison, v.32, n.4, p.972976, 1992.

HANSON, W.D. Seed protein content and delivery of assimilates to soybean seed embryos. Crop Science, Madison, v.31, n.6, p.1600-1604, 1991.

HOWELL, R.W.; CARTER, J.L. Physiological factors affecting composition of soybeans. I. Correlation of temperature during certain portions of the pod filling stage with oil percentage in mature beans. Agronomy Journal, Madison, n.45, p.526-528, 1953.

HUNGRIA, M.; CAMPO, R.J.; MENDES, I.C. Fixação biológica do nitrogênio com a cultura da soja. In: Workshop Nitrogênio na sustentabilidade de sistemas intensivos de produção agropecuária, Dourados, MS. Anais... Dourados: Embrapa Agropecuária Oeste, Embrapa Agrobiologia, 2000. p.51-75, (Documentos, 128)

HYMOWITZ, T.; COLLINS, F.I.; PANCZNER, J.; WALKER, W.M. Relationship between the content of oil, protein and sugar in soybean seed. Agronomy Journal, Madison, n.64, v. 5, p. 613-616, 1972.

IAPAR - Instituto Agronômico do Paraná. Clima do Paraná. 2006. Disponível em: <http://www.iapar.br/>. Acesso em 19 jul. 2006.

INSTITUTO ADOLFO LUTZ. Normas analíticas do Instituto Adolfo Lutz: métodos químicos e físicos para análise de alimentos. São Paulo, v.1, p. 533. 1985.

LARCHER, W. Trad.: PRADO, C.H.D.A. Ecofisiologia vegetal. São Carlos: RiMa artes e textos, p.341-418. 2000.

MANARA, N.T.F. Origem e expansão. IN: SANTOS, O.S. (Coord.) A cultura da soja 1 - Rio Grande do Sul, Santa Catarina e Paraná. Globo, 1988. p. 13-23.

MARCOS FILHO, J. Fisiologia de sementes de plantas cultivadas. Piracicaba: Fealq, 2005. 495p.

MARCOS FILHO, J. Produção de sementes de soja. Campinas: Fundação Cargill, 1986. 86p.

MORAES, M.V.P. Visão global do Mercado da soja: oportunidades e ameaças para o Brasil. In: CONGRESSO BRASILEIRO DE SOJA, 4., 2006, Londrina. Anais... Londrina: Embrapa Soja, 2006. p.15-19.

PIMENTEL-GOMES, F.; GARCIA, C.H. Estatística aplicada a experimentos agronômicos e florestais: exposição com exemplos e orientação para uso de aplicativos. Piracicaba: Fealq, 2002. 309 p.
PÍPOLO, A.E. Influência da temperatura sobre as concentrações de proteína e óleo em sementes de soja (Glycine max (L.) Merril). 128p. 2002. (Tese) Doutorado - Escola Superior de Agricultura "Luiz de Queiroz", Universidade de São Paulo, Piracicaba, 2002.

POPINIGS, F. Fisiologia da semente. 2.ed. Brasília: AGIPLAN, 1985. 289p.

RAMALHO, M.A.P; FERREIRA, D.F.; OLIVEIRA, A.C. A experimentação em genética e melhoramento de plantas. Lavras: UFLA, 2000. p.114-134.

RANGEL, M.A.S.; CAVALHEIRO, L.R.; CAVICHIOLLI, D.; CARDOSO, P.C. Efeito do genótipo e do ambiente sobre os teores de óleo e proteína nos grãos de soja, em quatro ambientes da Região Sul de Mato Grosso do Sul, safra 2002/ 2003. Dourados: Embrapa Agropecuária Oeste, 2004. (Boletim de pesquisa e desenvolvimento, 17)

RAO, A.C.S.; SMITH, J.L.; V.K.; JANDHYALA, R.I.; PARR, J.F. Cultivar and climatic effects on the protein content of soft white winter wheat. Agronomy Journal, Madison, v.85, p.10231028, 1993.

RASSINI, J.B.; LIN, S.S. Efeito de períodos de estiagens artificiais durante estádios de desenvolvimento da planta no rendimento e qualidade da semente de soja (Glycine max (L.) Merrill). Agronomia Sulriograndense, Porto Alegre, v.17, n.2, p. 225-237, 1981.

SACCOL, A.V. Ecologia e época de semeadura da soja. In: UNIVERSIDADE FEDERAL DE SANTA MARIA. Cultura da soja. Santa Maria: UFSM, 1975. p.50-62. (Boletim Técnico-DF, 5).

SEDIYAMA, T.; PEREIRA, M.G.; SEDIYAMA, C.S.; GOMES, J.L.L. Cultura da Soja, Parte I. Viçosa: UFV, 1993. 97p.

SIONIT, N.; KRAMER, P.J. Effect of water stress during different stages of growth of soybean. Agronomy Journal, Madison, v. 69 , n. 2, p.274-277, 1977.

TAIZ, L.; ZEIGER, E. Trad.:SANTARÉM, E.R. Fisiologia vegetal. 3.ed. Porto Alegre: Artmed, 2004. 613p.

URBEN FILHO, G.; SOUZA, P.I.M. Manejo da cultura da soja sob cerrado: Época, densidade e profundidade de semeadura. In: ARANTES, N.E.; SOUZA, P.I.M. (Ed.). Cultura da soja nos cerrados. Piracicaba: Potafos, 1993. p.216-218.

VITTI, G.C.; CAMARGO, M.A.F.; LARA, C. Síntese de análise químicas em tecido vegetal. Piracicaba: Departamento de Solos e Nutrição de Plantas, Escola Superior de Agricultura “Luiz de Queiroz", Universidade de São Paulo, 2001. 